\title{
The Potential of Strawberry, Rome Beauty Apple, and New Combination on Fasting Blood as Supporting Diet Therapy in Patients with Type II Diabetes Mellitus
}

\author{
Niken Yuliwati, ${ }^{1}$ Riezky Faisal Nugroho² \\ ${ }^{1}$ Nutrition Science Master Study Program, Universitas Sebelas Maret, Surakarta, Indonesia, \\ ${ }^{2}$ Department of Nutrition, Politeknik Kesehatan Kemenkes Surabaya, Surabaya, Indonesia
}

\begin{abstract}
Strawberries (Fragaria x ananassa) and Rome beauty apples (Malus sylvestris) contain high antioxidants to reduce oxidative stress and improve the glycemic response with diabetes mellitus (DM) type II. This study aimed to analyze the effect of strawberries, Rome beauty apples, and their combination to decrease fasting blood glucose levels of type II DM patients. This experimental research used a randomized pre-post-test with a control group design. Subjects were 44 patients divided into four groups: K (control, not given the fruit), P1 (strawberries 200 g/day), P2 (apples $300 \mathrm{~g} /$ day), and $\mathrm{P}_{3}$ (the combination strawberries $100 \mathrm{~g} /$ day, apples $150 \mathrm{~g} /$ day) for 14 days in FebruaryMarch 2019 in Surakarta. The inclusion criteria were DM patients aged 40-55 years who received oral antidiabetic drug therapy. Exclusion criteria were type II DM patients who, based on the doctor's diagnosis, had complications such as gastritis, hypertension, chronic renal failure, heart disease, liver disease, stroke, cancer, patients with consumption of antioxidant supplements. Mean of blood glucose level on K (149.82 \pm 39.125$), \mathrm{P} 1$ (141.00 \pm 38.079$)$, $\mathrm{P} 2$ (128.73 \pm 31.841$)$, and $\mathrm{P}_{3}(177.73 \pm 50.176)$. Analysis paired t test results showed a significant difference between before and after treatment $(\mathrm{p}=0.045)$. To find out which group was the most meaningful, the Bonferroni post hoc test. Decrease of fasting blood glucose levels with group K $(-10.55, \mathrm{p}>0.05), \mathrm{P} 1(-30.18, \mathrm{p}<0.05), \mathrm{P} 2$ (40.27, $\mathrm{p}<0.05)$, and $\mathrm{P}_{3}(-32.91, \mathrm{p}<0.05)$. ANOVA test was used to analyze, and the post hoc Bonferroni test with a control comparison was performed, resulting in $\mathrm{p}=0.028$, in $\mathrm{P} 2$ and $\mathrm{p}>0.05$ in $\mathrm{P} 1$ and $\mathrm{P} 3$. In conclusion, strawberries, Rome beauty apples, and their combination significantly decreased fasting blood glucose levels of type II DM patients, with the highest and most significant decrease in Rome beauty apples.
\end{abstract}

Key words: Apple, diabetes mellitus, diet therapy, strawberry

\section{Potensi Stroberi, Apel Rome Beauty, dan Kombinasi Baru terhadap Gula Darah Puasa sebagai Penunjang Terapi Diet pada Pasien Diabetes Melitus Tipe II}

\begin{abstract}
Abstrak
Stroberi (Fragaria x ananassa) dan apel Rome beauty (Malus sylvestris) mengandung antioksidan tinggi untuk mengurangi stres oksidatif dan memperbaiki respons glikemik pada diabetes melitus (DM) tipe II. Tujuan penelitian adalah menganalisis pengaruh buah stroberi, apel Rome beauty, dan kombinasinya terhadap penurunan kadar glukosa darah puasa pasien DM tipe II. Jenis penelitian eksperimen dengan rancangan randomized pre-post-test dengan control group design. Subjek penelitian 44 pasien yang dibagi empat kelompok, yaitu K (kontrol tidak diberi buah), P1 (stroberi $200 \mathrm{~g} /$ hari), P2 (apel Rome beauty $300 \mathrm{~g} / \mathrm{hari}$ ) dan P3 (kombinasi stroberi $100 \mathrm{~g} / \mathrm{hari}$ dan apel 150 g/hari) selama 14 hari pada bulan Februari-Maret 2020 di Surakarta. Kriteria inklusi adalah pasien DM usia 40-55 tahun yang mendapat terapi obat antidiabetik oral. Kriteria eksklusi adalah pasien DM tipe II yang berdasar atas diagnosis dokter mengalami komplikasi seperti mag, hipertensi, gagal ginjal kronik, penyakit jantung, penyakit hati, strok, kanker, dan pasien dengan konsumsi suplemen antioksidan. Kadar glukosa darah rerata pada K $(149,82 \pm 39,125), \mathrm{P}_{1}(141,00 \pm 38,079)$, P2 $(128,73 \pm 31,841)$, dan $\mathrm{P}_{3}(177,73 \pm 50,176)$. Hasil analisis paired $t$ test menunjukkan terdapat perbedaan yang signifikan antara sebelum dan sesudah perlakuan $(\mathrm{p}=0,045)$. Untuk mengetahui kelompok mana yang paling bermakna, dilakukan Uji Post Hoc Bonferroni. Penurunan kadar glukosa darah puasa pada K (-10,55; p>0,05), P1 (-30,18; p<0,05), P2 (-40,27; p<0,05), dan P3 (-32,91; p<0,05). Analisis dilakukan dengan uji ANOVA dan Uji Post Hoc Bonferroni dengan perbandingan kontrol menghasilkan $\mathrm{p}=0,028$ pada $\mathrm{P} 2$ serta p >0,05 pada $\mathrm{P} 1$ dan $\mathrm{P}_{3}$. Simpulan, pemberian stroberi, apel Rome beauty, dan kombinasinya signifikan menurunkan kadar glukosa darah puasa pasien DM tipe II dengan penurunan tertinggi dan bermakna pada apel Rome beauty.
\end{abstract}

Kata kunci: Apel, diabetes melitus, stroberi, terapi diet

Received: 13 July 2020; Revised: 11 April 2021; Accepted: 15 April 2021; Published: 30 April 2021

Correspondence: Niken Yuliwati, SST., M.Gz. Nutrition Science Master Study Program, Universitas Sebelas Maret Surakarta. Jln Ir. Sutami 36 A, Surakarta 57126, Central Java, Indonesia. E-mail: nikenyuliwatio3@gmail.com 


\section{Introduction}

Diabetes mellitus defined as a syndrome of metabolic disease. ${ }^{1}$ Metabolism of carbohydrates, proteins, and fats that are impaired in diabetes is caused by decreased insulin sensitivity, insulin secretion, or both, characterized by chronic hyperglycemia. ${ }^{2}$ The number of people with diabetes mellitus in 2017 was 425 million. This number is expected to increase every year, and in 2045 it will reach 629 million. ${ }^{3}$ Based on the report on Riskesdas 2018, ${ }^{4}$ the prevalence of diabetes mellitus in Indonesia increased to 10.9\% in 2018. This number increased by $4 \%$ compared to 2013. Prevention and management of diabetes mellitus are very important, that the necessary complementary alternative. ${ }^{5}$

Diabetes mellitus type II is caused by decreased insulin secretion or increase insulin resistance. It is related to reduced insulin secretion due to inflammation, metabolic stress, and genetic factors where $\beta$-cell dysfunction is the underlying factor. ${ }^{6}$ Insulin resistance is caused by many factors, one of which is the oxidative stress factor. Oxidative stress is a condition of imbalance between free radicals and antioxidant systems, which causes decreased peripheral insulin sensitivity. ${ }^{7}$ Reactive oxygen species (ROS) in the mitochondria result in increased endoplasmic reticulum stress and oxidative stress on $\beta$-cells that cannot respond to hyperglycemia. ROS also damages cellular components such as lipids, proteins, and DNA and triggers changes in transcription that increase insulin resistance. ${ }^{8}$ Oxidative stress has an essential role in the development of DM type II. An external source of antioxidants can help address this oxidative stress. Therefore, the use of antioxidant agents is a promising new therapeutic strategy. Functional foods that have the effect of reducing blood glucose (hypoglycemic) levels are now considered as alternatives to drugs. ${ }^{9}$ Routine intake of functional foods can improve sustained or chronic stress in diabetes mellitus through the antioxidant properties contained in functional foods. ${ }^{10}$

Strawberry antioxidants have hypoglycemic activity in diabetes mellitus. ${ }^{11}$ Anthocyanins are part of the antioxidants in strawberries with very high levels, which affect lowering blood glucose levels, reducing blood vessel inflammation, and endothelial dysfunction. ${ }^{12}$ Quercetin is a flavonoid found in fruits such as apples which functions as an anti-diabetic. This powerful antioxidant can prevent oxidative stress and delay the development of complications of diabetes mellitus. ${ }^{13}$ This study was conducted to analyze the effect of administering strawberries, Rome beauty apples, and their combination to decrease patients' fasting blood glucose levels with diabetes mellitus type II.

\section{Methods}

This experimental study used a pretest-posttest control-group design. The subjects were diabetes mellitus type II patients at the public health centers in Kratonan, Ngoresan, Sangkrah, and Banyuanyar in the area of Surakarta city from February to March 2020. The inclusion criteria were patients with diabetes mellitus type II, male and female, aged 40-55 years who took only oral antidiabetic drugs, consumed fresh fruit, and communicated well. The subjects were measured for their body weight and height to determine their body mass index (BMI), a statistical index that describes nutritional status. The formula for calculating BMI is the weight $(\mathrm{kg})$ divided by height $\left(\mathrm{m}^{2}\right)$. BMI is classified as underweight (under $18.5 \mathrm{~kg} / \mathrm{m}^{2}$ ), normal (greater than or equal to 18.5 to less than $24.9 \mathrm{~kg} / \mathrm{m}^{2}$ ), overweight (greater than or equal to 25.0 to less than $27.0 \mathrm{~kg} /$ $\mathrm{m}^{2}$ ), and obesity (greater than $\left.27.0 \mathrm{~kg} / \mathrm{m}^{2}\right) .{ }^{14} \mathrm{BMI}$ is used as a weight correction factor in calculating energy requirements. Then, the subjects were given education about the benefits of physical activity and a therapeutic diet using the diabetes mellitus leaflet and a list of food exchanges. The subjects who met the inclusion criteria at four health centers were randomized, which resulted in 44 people. Respondents were divided into four groups, group K (control group, not given the fruit), group P1 (given strawberries $200 \mathrm{~g} /$ day, obtained directly from farmers in Cemoro Kandang Strawberry Farm, Gondosuli village, Tawangmangu subdistrict, Karanganyar regency, Central Java province).

Group P2 (given Rome beauty apples 300 $\mathrm{g} /$ day) from farmers in Andonosari village, Pasuruan regency and group $\mathrm{P}_{3}$ (given the combination of strawberries $100 \mathrm{~g} /$ day and apples $150 \mathrm{~g} /$ day) for 14 days. The researcher explained the purpose and the procedure of the study before the subjects signed an informed consent form. The subjects fasted at least 8-12 hours before checking their fasting blood glucose levels. The 
hexokinase method was used to measure fasting blood glucose levels on the first day before the intervention and the fifteenth day after the intervention. The examination was at the CITO Surakarta laboratory. It received accreditation from the National Accreditation Committee (KAN) LM-06o-IDN using the INDIKO tool. The fruits were delivered to the respondents' houses every day for two times snacks, in the morning and afternoon for 14 days.

The SPSS version 22 program was used to process and analyze the data. The descriptive analysis of research variables was performed with frequency distribution tables and percentages, including gender, age, education, and BMI. The analysis of mean differences before and after the intervention was conducted using Paired $t$ test. The analyses of differences in the effect of administering strawberries, Rome beauty apples, and their combinations were carried out using the one-way ANOVA test because the data were normally distributed. There was a significant difference $(\mathrm{p}<0.05)$ between the groups, so the posthoc test was performed to analyze the most different interventions in the strawberry, Rome apple, and combination groups with a confidence level of 95\%. The Health Research Ethics Committee of Dr. Moewardi Regional General Hospital Surakarta has approved this research, with the ethical clearance number: 087/I/ HREC/2020.

\section{Results}

Statistically, the distribution of research subjects between the control group, strawberries, Rome beauty apples, and the combination based on
Table 1 Characteristics of Subjects

\begin{tabular}{lc}
\hline Characteristics & $\mathbf{n = 4 4}$ (\%) \\
\hline Gender & \\
Female & $10(23)$ \\
Male & $34(77)$ \\
Age (years) & \\
$40-45$ & $9(21)$ \\
$46-50$ & $11(25)$ \\
$51-55$ & $24(54)$ \\
Education & \\
Elementary school & $16(36)$ \\
Junior high school & $10(23)$ \\
Senior high school & $16(36)$ \\
University & $2(5)$ \\
Profession & \\
Housewife & $22(50)$ \\
Private employee & $11(25)$ \\
Entrepreneur & $11(25)$ \\
Body mass index & \\
Normal & $24(54)$ \\
Overweight & $6(14)$ \\
Obesity & $14(32)$ \\
\hline
\end{tabular}

the characteristics of gender, age, education, occupation, nutritional status showed no difference $(p>0.05)$. Table 1 showed the female patients dominate the distribution of research subjects (34/77\%). The subjects' age range in this study was $51-55$ years (54\%). The education was an elementary school and high school respectively( $36 \%)$. Half of the subjects were a housewife. The average BMI scores in the control group were $25.28 \mathrm{~kg} / \mathrm{m}^{2}$, the strawberry group $24.65 \mathrm{~kg} / \mathrm{m}^{2}$, the Rome beauty apple group 25.50

Table 2 Comparison of Average Blood Glucose Levels Between Groups Before and After Intervention

\begin{tabular}{|c|c|c|c|c|}
\hline \multirow[b]{2}{*}{ Groups } & \multicolumn{2}{|c|}{ Duration } & \multirow{2}{*}{$\begin{array}{c}\text { Decrease Fasting } \\
\text { Blood Glucose } \\
\text { (Mean } \pm \text { SD) } \\
\text { mg/dL }\end{array}$} & \multirow[b]{2}{*}{$\mathbf{p}^{\mathbf{a}}$} \\
\hline & $\begin{array}{c}\text { On Day-o } \\
\text { (Mean } \pm \text { SD }) \\
\text { mg/dL }\end{array}$ & $\begin{array}{c}\text { On Day-15 } \\
(\mathrm{Mean} \pm \mathrm{SD}) \\
\mathrm{mg} / \mathrm{dL}\end{array}$ & & \\
\hline $\mathrm{K}$ & $160.36 \pm 46.807$ & $149.82 \pm 39.125$ & $10.55 \pm 16.263$ & 0.057 \\
\hline $\mathrm{P} 1$ & $172.09 \pm 28.648$ & $141.00 \pm 38.079$ & $30.18 \pm 29.253$ & $0.004^{*}$ \\
\hline $\mathrm{P} 2$ & $170.73 \pm 41.478$ & $128.73 \pm 31.841$ & $40.27 \pm 23.018$ & $<0.001^{*}$ \\
\hline $\mathrm{P}_{3}$ & $209.64 \pm 61.112$ & $177 \cdot 73 \pm 50.176$ & $32.91 \pm 22.488$ & $0.001^{*}$ \\
\hline $\mathrm{p}^{\mathrm{b}}$ & 0.080 & $0.045^{*}$ & $0.030^{*}$ & \\
\hline
\end{tabular}

Note: * significant differences ( $\mathrm{p}<0.05), \mathrm{K}=$ control, $\mathrm{P} 1=$ strawberries, $\mathrm{P} 2=$ Rome beauty apples, $\mathrm{P}_{3}=$ combination of strawberries and apples, $\mathrm{a}=$ paired $\mathrm{t}$ test, $\mathrm{b}=$ one-way ANOVA 
Table 3 Comparison of Mean Difference of Fasting Blood Glucose Levels Based on Bonferroni Post Hoc Test

\begin{tabular}{|c|c|c|c|}
\hline \multicolumn{2}{|c|}{ Groups } & Mean Difference & $\mathbf{p}$ \\
\hline $\mathrm{K}$ & $\mathrm{P} 1$ & 19.636 & 0.325 \\
\hline K & $\mathrm{P}_{2}$ & 29.727 & $0.028^{*}$ \\
\hline K & $\mathrm{P}_{3}$ & 22.364 & 0.176 \\
\hline P1 & $\mathrm{P}_{2}$ & 10.091 & 1.000 \\
\hline P1 & $\mathrm{P}_{3}$ & 2.727 & 1.000 \\
\hline P2 & $\mathrm{P}_{3}$ & $7 \cdot 364$ & 1.000 \\
\hline
\end{tabular}

$\mathrm{kg} / \mathrm{m}^{2}$, and $25.36 \mathrm{~kg} / \mathrm{m}^{2}$. Most of the total study subjects had $54 \%$ normal nutritional status.

The results of the paired $t$ test based on Table 2 showed that the groups administered with strawberries, Rome beauty apples, and their combination experienced a significant decrease in fasting blood sugar levels $(\mathrm{p}<0.05)$ after the intervention, but the control group experienced an insignificant decrease $(\mathrm{p}=0.057)$. A one-way ANOVA test was conducted to determine the presence or absence of significant differences between treatment groups. Table 2 showed that based on the one-way ANOVA test, there were no significant differences in the fasting blood glucose levels between the four groups at the pretest $(\mathrm{p}=0.08 \mathrm{o})$. Meanwhile, at the posttest, there were significant differences in each group $(\mathrm{p}=0.045)$.

Based on Table 3, it is known that the Bonferroni post hoc test results showed a significant decrease in fasting blood glucose levels between the control group and the Rome beauty apple group $(\mathrm{p}=\mathrm{0.028})$. On the one hand, the strawberry and the combination groups did not show significantly different results with $\mathrm{p}=0.325$ and $\mathrm{p}=0.176$, respectively. Based on the Bonferroni posthoc test results compared to the combination group, the strawberry group and the Rome beauty apple group obtained the same result ( $\mathrm{p}=1.000)$.

\section{Discussion}

The results of the paired $t$ test showed that the average decrease in blood glucose levels in $\mathrm{Q}$ patients with DM who were given 200 grams of strawberries per day for 14 days was 30.18 $\mathrm{mg} / \mathrm{dL}$ (Table 2). It is caused by anthocyanin content in strawberries which can reduce fasting blood glucose levels. ${ }^{12}$ Strawberries contain anthocyanins $171.4 \mathrm{ppm} \quad \mathrm{wb} / 100$ grams. ${ }^{14}$ Anthocyanins control carbohydrate metabolism in the body by increasing PPARy activation in the skeletal muscle and tissue, translocation, expression of glucose transporter 4 (GLUT4), and the secretion of adiponectin and leptin. Anthocyanins activate AMP-activated protein kinase (AMPK), which stimulates glucose uptake and insulin secretion by pancreatic $\beta$-cells and decreases $\mathrm{RBP}_{4}$ to increase insulin sensitivity. Anthocyanins also have the effect of inhibiting intestinal $\alpha$-glucosidase, pancreatic $\alpha$-amylase which slows glucose absorption after meals, thereby preventing postprandial hyperglycemia and increasing insulin secretion. ${ }^{15}$

The results of this study are similar to those of Putri et al.'s ${ }^{12}$ study, which states that the administration of strawberry juice with a dose of $3.6 \mathrm{~mL} / 200 \mathrm{gBW} /$ day (made from $274 \mathrm{~g}$ of strawberries) for 14 days decreases fasting blood glucose levels of rats with DM type II (mean=163.82 mg/dL, p<0.05). ${ }^{15}$ Administering a strawberry powder drink of $20 \mathrm{~g} /$ day (made from $330 \mathrm{~g}$ of strawberries) in obese subjects with insulin-resistant abdomen for 14 days did not significantly decrease blood glucose levels (mean $=35 \mathrm{mg} / \mathrm{dL}, \mathrm{p}>0.05$ ). Increasing the dose to $40 \mathrm{~g} /$ day (440 $\mathrm{g}$ of strawberries) had a significant result $(\mathrm{p}<0.05)$ with an average decrease of 84 $\mathrm{mg} / \mathrm{dL}^{16}$

The average decrease in fasting blood glucose levels of patients with DM who were given $300 \mathrm{~g}$ of Rome beauty apples per day in this study was $40.27 \mathrm{mg} / \mathrm{dL}$ (Table 3). Apple Rome beauty contains quercetin $4,189 / 100 \mathrm{mg} / \mathrm{kg} .{ }^{17}$ This is caused by the content of quercetin in apples which has the effect of lowering blood glucose levels. Quercetin reduces blood sugar levels by inducing PPARY expression, reducing intestinal glucose absorption, increasing glucose uptake in organs and tissues as well as insulin resistance, and reducing oxidative stress. ${ }^{13}$ Quercetin has anti-hyperglycemic activity in diabetes. ${ }^{18,19}$ Apple consumption has beneficial health effects, one of which is to manage diabetes mellitus type II. Polyphenols in apples have antioxidant activity and inhibit the activity of $\alpha$-glucosidase. ${ }^{20}$ Quercetin reduces oxidative stress by increasing 
antioxidants, decreasing malondialdehyde and nitric oxide levels, and activating gene expression related to the PI3K/PKB signaling pathway, which modulates glucose metabolism resulting in a decrease in fasting blood sugar levels. ${ }^{21}$

The results of this study are in line with the study in the chronic disease management program (program pengelolaan penyakit kronis, Prolanis) group at the Genuk Public Health Center in Semarang with the intervention of manalagi apples for 14 days. They found that there were decreased fasting blood sugar levels in patients with diabetes mellitus type II who were given $200 \mathrm{~g}, 300 \mathrm{~g}$, and $400 \mathrm{~g}$ of manalagi apples per day with a higher average decrease of $98.83 \mathrm{mg} / \mathrm{dL}, 124.33 \mathrm{mg} / \mathrm{dL}$, and $150.16 \mathrm{mg} / \mathrm{dL}$, respectively. The higher the dose of fruit is given, the higher its effect on decreasing fasting blood glucose levels will be. ${ }^{22}$ Another similar study in hyperglycemic rats. The study found that giving manalagi apples to hyperglycemia rats at a dose of $20 \mathrm{~g} / 200 \mathrm{gBW}$ for 28 days could decrease their fasting blood glucose levels with an average decrease of $130.87 \mathrm{mg} / \mathrm{dL}^{23}$

Giving a combination of 100 grams of strawberries and 150 grams of Rome beauty apples per day for 14 days in this study could significantly decrease fasting blood glucose levels of diabetes mellitus type II patients with $\mathrm{p}<0.05$ and an average decrease of $32.91 \mathrm{mg} / \mathrm{dL}$. The results of the Bonferroni post hoc test showed that the differences in the average fasting blood glucose levels between the $\mathrm{P}_{1} \& \mathrm{P}_{3}$ and $\mathrm{P}_{2} \& \mathrm{P}_{3}$ groups were not significantly different. It means that the $\mathrm{P}_{3}$ dose had the same effectiveness as $\mathrm{P}_{1}$ and P2 doses in reducing fasting blood glucose levels in patients with diabetes mellitus type II.

The decrease in fasting blood glucose levels in $\mathrm{P}_{3}$ is lower than $\mathrm{P}_{2}$. It is possible because the strawberries and Rome beauty apples are served in the form of fresh fruits so that the combination of fruit cannot be mixed evenly. As a result, the interaction of the phenolic compounds of the two fruits that produce a more hypoglycemic effect height cannot take place to the maximum. Besides, the composition of strawberries and apples is $50 \%$ of the $\mathrm{P} 1$ dose and $50 \%$ of the $\mathrm{P}_{2}$ dose. In comparison, the $\mathrm{P}_{3}$ dose was with a combination of $40 \%$ of strawberries and $60 \%$ of Rome beauty apples. The proportion of fruit combinations may not produce a more significant hypoglycemic effect than the effect of fruit without a combination (P1 and P2). The result showed a combination of juice with $20 \%$ of strawberries and $80 \%$ of apples had the highest hypoglycemia effect compared to other proportions, which are 30/70, 40/60, and 50/50. ${ }^{24}$

Phenols in apples contribute more to the $\alpha$-amylase and $\alpha$-glucosidase inhibitory activity in a combination of blueberries and apples. Fruit combination processing to juice has the potential to produce a more optimal interaction of phenolic compounds. It can release phenols bound into the water while maintaining antioxidant activity in the fruit to produce a higher hypoglycemic effect. The phenolic composition and $\mathrm{pH}$ influence the hypoglycemic effect of the fruit combination, and enzymes contained in the proportion of fruit combinations. ${ }^{24}$

\section{Conclusions}

Provision of strawberries and Rome beauty apples and their combination significantly decrease fasting blood glucose levels of patients with diabetes mellitus type II. Giving Rome beauty apples had a significant effect on reducing fasting blood glucose and LDL-C levels.

\section{Conflict of Interest}

There is no conflict of interest in this study.

\section{Acknowledgments}

We would like to thank the support from the Head of Public Health Centers in Kratonan, Ngoresan, Sangkrah, and Banyuanyar in the area of Surakarta city.

\section{References}

1. Fathonah R, Indriyanti A, Kharisma Y. Labu kuning (Cucurbita moschata Durch.) untuk penurunan kadar glukosa darah puasa pada tikus model diabetik. GMHC. 2014;2(21):2733 .

2. Poznyak A, Grechko AV, Poggio P, Myasoedova VA, Alfieri V, Orekhov AN. The diabetes mellitus atherosclerosis connection: the role of lipid and glucose metabolism and chronic inflammation. Int $\mathrm{J}$ Mol Sci. 2020;21(5):1835.

3. International Diabetes Federation. IDF diabetes atlas. $8^{\text {th }}$ Edition. Brussel: International Diabetes Federation; 2017. 
4. Badan Penelitian dan Pengembangan Kesehatan, Kementerian Kesehatan Republik Indonesia. Hasil utama Riskesdas 2018 [Internet]. Jakarta; Badan Penelitian dan Pengembangan Kesehatan, Kementerian Kesehatan Republik Indonesia; 2019 [cited 2020 January 15]. Available from: https:// www.litbang.kemkes.go.id/hasil-utamariskesdas-2018.

5. Jasaputra DK, Rahardja F, Christian E. Efek jus gel lidah buaya (Aloe vera L.) dalam menghambat penyerapan glukosa di saluran cerna pada manusia. GMHC. 2014;2(1):1-5.

6. American Diabetes Association. 7 . Diabetes technology: standards of medical care in diabetes-2020. Diabetes Care. 2020;43(Suppl 1):S77-88.

7. Yaribeygi H, Sathyapalan T, Atkin SL, Sahebkar A. Molecular mechanisms linking oxidative stress and diabetes mellitus. Oxid Med Cell Longev. 2020;2020:8609213.

8. Burgos-Morón E, Abad-Jiménez $\mathrm{Z}$, de Marañón AM, Iannantuoni F, EscribanoLópez I, López-Domènech $\mathrm{S}$, et al. Relationship between oxidative stress, ER stress, and inflammation in type 2 diabetes: the battle continues. J Clin Med. 2019;8(9):1385.

9. Mihaylova D, Popova A, Alexieva I, Krastanov A, Lante A. Polyphenols as suitable control for obesity and diabetes. Open Biotechnol J. 2018;12:219-28.

10. Alkhatib A, Tsang C, Tiss A, Bahorun T, Arefanian H, Barake R, et al. Functional foods and lifestyle approaches for diabetes prevention and management. Nutrients. 2017;9(12):1310.

11. Sarkar D, Ankolekar C, Shetty K. Beneficial lactic acid bacteria (LAB)-based biotransformation of plant and dairy substrates to enhance type 2 diabetesrelevant health benefits. In: Shetty K, Sarkar D, editors. Functional foods and biotechnology: biotransformation and analysis of functional foods and ingredients. Boca Roton: CRC Press; 2020. p. 345-60.

12. Putri MD, Wiboworini B, Dirgahayu $P$. The effect of strawberry on type 2 diabetes mellitus: a review. Int J Nutr Sci. 2020;5(1): $1-6$.

13. Shi GJ, Li Y, Cao QH, Wu HX, Tang XY, Gao $\mathrm{XH}$, et al. In vitro and in vivo evidence that quercetin protects against diabetes and its complications: a systematic review of the literature. Biomed Pharmacother. 2019;109:1085-99.

14. Yuliwati N. Laporan hasil analisis buah apel dan stroberi. Surakarta: Laboratorium Pangan dan Gizi, Jurusan Teknologi Pertanian, Fakultas Pertanian, Universitas Sebelas Maret; 2020 [unpublished].

15. Różańska D, Regulska-Ilow B. The significance of anthocyanins in the prevention and treatment of type 2 diabetes. Adv Clin Exp Med. 2018;27(1):135-42.

16. Park E, Edirisinghe I, Wei H, Vijayakumar LP, Banaszewski K, Cappozzo JC, et al. A dose-response evaluation of freeze-dried strawberries independent of fiber content on metabolic indices in abdominally obese individuals with insulin resistance in a randomized, single-blinded, diet-controlled crossover trial. Mol Nutr Food Res. 2016;60(5):1099-109.

17. Yuliwati N. Laporan hasil uji buah apel, stroberi dan kombinasi. Yogyakarta: Laboratorium Penelitian dan Pengujian Terpadu Universitas Gadjah Mada; 2020 [unpublised].

18. Bule M, Abdurahman A, Nikfar S, Abdollahi M, Amini M. Antidiabetic effect of quercetin: a systematic review and meta-analysis of animal studies. Food Chem Toxicol. 2019;125:494-502.

19. Al-Ishaq RK, Abotaleb M, Kubatka P, Kajo K, Büsselberg D. Flavonoids and their anti-diabetic effects: cellular mechanisms and effects to improve blood sugar levels. Biomolecules. 2019;9(9):430.

20. de Oliveira Raphaelli C, dos Santos Pereira E, Camargo TM, Vinholes J, Rombaldi CV, Vizzotto M, et al. Apple phenolic extracts strongly inhibit a-glucosidase activity. Plant Foods Hum Nutr. 209;74(3):430-35.

21. Ying L, Chaudhry MT, Xiao F, Mao Y, Wang M, Wang B, et al. The effects and mechanism of quercetin dietary supplementation in streptozotocin-induced hyperglycemic arbor acre broilers. Oxid Med Cell Longev. 2020;2020:9585047.

22. Ayuhapsari N, Wijaningsih W, Jaelani M. Efektifitas pemberian buah apel manalagi dengan dosis bervariasi terhadap penurunan kadar glukosa darah pada penderita diabetes mellitus tipe ii di kelompok prolanis Puskesmas Genuk Kota Semarang. J Ris Gizi. 
2018;6(2):13-8.

23. Yuliwar R. Jus apel manalagi dan kadar glukosa darah tikus putih yang mengalami hiperglikemia. JIKI. 2017;3(2):145-57.

24. Agustinah W, Sarkar D, Woods F, Shetty K.
Apple and blueberry synergies for designing bioactive ingredients for the management of early stages of type 2 diabetes. J Food Qual. 2016;39(4):370-82. 